\title{
Recent land cover and use in Romania: A conservation perspective
}

\author{
Alexandru-Ionuţ Petrişor 1, 2* (iiliana Elza Petrişor ${ }^{3}$ \\ 1, "Ion Mincu" University of Architecture and Urban Planning, Bucharest, Romania \\ 2 National Research Institute for Tourism, Bucharest, Romania \\ 3 Architect, independent researcher \\ * Correspondence: alexandru_petrisor@yahoo.com
}

Keywords: deforestation, agricultural abandonment, urbanization, transition, unplanned development, natural protected areas.

\begin{abstract}
The study of land cover and use changes is important for sustainability, given that they are part of the global changes affecting our environment. In order to understand the mechanisms determining them, land cover and use changes must be studied based on their associated transitional dynamics. The present research aims to look at the most recent land cover and use changes from Romania, chosen as an example for post-socialists transitions. The methodology was based on applying geo-spatial analyses to data on land cover and use changes and natural protected areas. The results indicate that the most prominent transitional dynamics are deforestations and abandonment of cropland, rooted in the post-socialist property restitution. Furthermore, the study identified transitional dynamics indicating the human pressure within the natural protected areas, including urbanization, development of agriculture, and deforestation. Although subject to limitations bound to the use of CORINE data, the findings are important for understanding the environmental impact of socio-economic drivers, and provide additional evidence for the fact that emerging economies tend to sacrifice the environment during the economic crises.
\end{abstract}

\section{Introduction}

The importance of studying land cover and use changes (LCUCs) has been stressed out repeatedly, in relationship to sustainability (Verburg et al., 1999; Lambin et al., 2000; Foley et al., 2005); as part of the 'global changes' (Dale, 2011; Faeth and Hanson, 2016), LCUCs measure the human pressure against the environment (Elias et al., 2012). From this perspective, their extent might have a direct association with the human footprint (Chambers et al., 2000; Petrişor, 2016b). LCUCs are also associated with the 'transitional dynamics' (Lambin and Meyfroidt, 2010), which are in fact their socio-economic drivers. The transitional dynamics represent the conversion of a given land cover/use (or their sets) into another land cover/use (Petrişor et al., 2014, 2020); some of them are ascertained based on the initial use (e.g., deforestation), others by the final one (e.g., urbanization). Comparative studies carried out across Europe have pinpointed differences between the West and the East (Kupková et al., 2013). Moreover, the intensity and dominance of transitional dynamics varies in time for the same place (Baumann et al., 2011).

For this reason, and also given the potential use of land cover and use data in other sectors, such as planning (Grădinaru et al., 2017; Ianoş et al., 2017; Cocheci et al., 
2019; Popa and Enache, 2019), the European Union established several programs, one replacing the other, for collecting data to monitor LCUCs across the continent (Petrişor et al., 2010; Hagenauer and Helbich, 2012; Petrişor and Petrişor, 2015; Bielecka and Jenerowicz, 2019). The main output consists of the CORINE data, updated each 6 years. The period is suitable for monitoring long-term transitional dynamics at national and regional scales (Petrişor and Petrişor, 2015).

Transition economies are true 'laboratories' for examining the transitional dynamics (Kuemmerle et al., 2006, 2007, 2008, 2009; Hostert et al., 2008, 2011; Müller and Munroe, 2008; Müller et al., 2009; Sikor et al., 2009; Václavík and Rogan, 2009; Bălteanu et al., 2010; Dragotă et al., 2011; Grigorescu et al., 2012a, b; Knorn et al., 2012; Kupková et al., 2013; Popovici et al., 2013, 2018; Prishchepov et al., 2013; Dumitraşcu et al., 2014; Bičík et al., 2015; Vanonckelen and Van Rompaey, 2015; Andronache et al., 2016; Ianoş et al., 2016; Drăghici et al., 2017; Pintilii et al., 2017; Grigorescu et al., 2018; Kucsicsa and Dumitrică, 2019; Ianoş and Jones, 2019; Kucsicsa et al., 2019). The often disruptive processes associated with shifts of the global policies, such as the EU accession, results into important changes of the trends associated with the transitional dynamics (Kuemmerle et al., 2006, 2007, 2008, 2009; Hostert et al., 2008, 2011; Müller and Munroe, 2008; Müller et al., 2009; Sikor et al., 2009; Václavík and Rogan, 2009; Kupková et al., 2013; Prishchepov et al., 2013; Bičík et al., 2015; Vanonckelen and Van Rompaey, 2015). Romania is a good example (Kuemmerle et al., 2008, 2009; Hostert et al., 2008; Müller et al., 2009; Bălteanu et al., 2010; Dragotă et al., 2011; Ianoş et al., 2011; Grigorescu et al., 2012a, b; Knorn et al., 2012; Petrişor, 2012a, b, 2015a, b, 2016a, 2017, 2018; Popovici et al., 2013, 2018; Dumitraşcu et al., 2014; Petrişor and Petrişor, 2015, 2017a, 2018; Vanonckelen and Van Rompaey, 2015; Petrişor et al., 2010, 2014; Andronache et al., 2016; Ianoş et al., 2016; Stan and Vintilă, 2016; Drăghici et al., 2017; Pintilii et al., 2017; Grigorescu et al., 2018; Kucsicsa and Dumitrică, 2019; Kucsicsa et al., 2019); while the first transitional dynamics assessed based on the use of CORINE indicated the effects of property restitution (abandonment of restituted cropland and deforestation of restituted forests), the next periods indicate the real estate boom and then the effects of the economic crisis (Munteanu and Servilo, 2013). A characteristic of Romania is the unplanned development (or planning for short term), visible through pairs of antagonistic transitional dynamics (development or growth vs. decline or loss) acting together in different areas during the same period (Petrişor, 2012a, b, 2015a, b, 2016a, 2017; Petrişor et al., 2010, 2014).

One of the requirements associated with the accession to the EU was the creation of networks of protected areas, by expanding the existing ones and creating new sites (Stăncioiu et al., 2010; Kati et al., 2015; Vanonckelen and Van Rompaey, 2015). The process was done at a very fast past pace, often with a poor substantiation (Petrişor, 2018), resulting into a lawsuit against Romania from the EU (Cojocariu et al., 2010). Different studies indicated that the Romanian natural protected areas cover preferentially critical areas, such as the mountains (Petrişor and Petrişor, 2017a) and wetlands (Petrişor, 2010). However, the protection status was not always enforced (Petrişor, 2018). Its enforcement resulted into the regeneration of forests over the former agricultural areas (Blakesley, 2006; Agnoletti et al., 2011; Van Uytvanck, 2009; Petrişor 
et al., 2014). However, this phenomenon is characteristic to other countries as well (Agnoletti et al., 2011; Blakesley, 2006; Müller et al., 2008; Sikor et al., 2009; Van Uytvanck, 2009; Prishchepov et al., 2013). In Romania, its particularity is the occurrence in natural protected areas, but also in the cropland areas abandoned after being restituted to their owners (Müller et al., 2009; Popovici et al., 2018). Normally the protection status implies the lack of any other LCUCs than those resulted from the colonization of protected areas by nature, but previous studies have indicated the presence of other LCUCs in non-protected areas too (Petrişor and Petrişor, 2017b).

Starting from this background, the present study aims to: (1) look at the most recent (2012-2018) LCUCs in Romania, by analyzing their spatial distribution over the Romanian regions of development in connection to the associated transitional dynamics, and (2) assess whether these LCUCs show different patterns within the natural protected areas.

\section{Data and methods}

The study used two data sets. 2012-2018 data on LCUCs is provided free of charge through the Copernicus Land Monitoring Services (https://land.copernicus.eu/pan-european/corine-land-cover/lcc-2012-2018/view). The data has a spatial resolution of 5 hectares and comes into an ArcGIS format. In order to use the data, it was converted to ArcView GIS 3.X format, sub-sampled for Romania, and re-projected unto Stereo 1970. Data on the Romanian natural protected areas is freely available from the Romanian Ministry of Environmental Protection through their dedicated Internet

page (http://www.mmediu.ro/beta/domenii/protectia-naturii-2/arii-naturale-protejate/). The data comes already in an ArcView GIS 3.X format, using the Stereo 1970 projection. Data on the Romanian regions of development comes from the free Geo-Spatial Portal; the limits were derived from the county limits (http://www.geo-spatial.org/file_download/29525), a file provided in an ArcView GIS 3.X format, using the Stereo 1970 projection.

The classification scheme used to ascertain the transitional dynamics corresponding to each LCUC combines those defined by the previous studies (Ianoş et al., 2011; Petrişor, 2012a, b, 2015a, b, 2016a, 2017, 2018; Petrişor and Petrişor, 2015, 2017a, 2018; Petrişor et al., 2010, 2014, 2020), completing them; in more details, the definitions of the transitional dynamics are presented below:

1. Urbanization is a change of natural, agricultural, wetland or water zones in urban ones or changes within the urban areas showing that the city developed;

2. Forestation is defined based on 'forests', corresponding to CORINE classes 3.1.1 (coniferous forests), 3.1 .2 (broadleaved forests), and 3.1.3 (mixed forests); the term includes two phenomena, i.e. afforestation and reforestation (Dutcă and Abrudan, 2010), which are the change of urban, agricultural, wetland or water areas into 'forests'. The colonization of abandoned cropland by forest vegetation (Garcia-Ruiz et al., 1996; Blakesley, 2006; Kuemmerle et al., 2006; Václavík and 
Rogan, 2009; Van Uytvanck, 2009; Agnoletti et al., 2011; Petrişor et al., 2014), and changes of other natural categories into forests are included;

3. Deforestation is the change of 'forests' into other natural classes;

4. The development of agriculture is a process including the change of urban, natural, wetland or water areas into agricultural parcels, and inner changes of the agricultural areas suggesting that the agriculture develops;

5. The abandonment of agriculture is defined as a change of agricultural areas suggesting the decline or abandonment of agriculture;

6. Floods include the changes of urban, agricultural, or natural areas into wetlands or waters, and the transformation of wetlands into waters;

7. Drought is a process implying the change of wetlands or waters into urban, agricultural, or natural areas, or the change of waters into wetlands.

The methodology consisted of spatial analyses carried out in ArcView 3.X: overlaying the data sets, intersecting them, performing computations in Microsoft Excel 2003 based on the attributes, and computations performed using the X-Tools extension of ArcView 3.X.

\section{Results and discussion}

The spatial distribution of LCUCs occurred in Romania during 2012-2018 by transitional dynamics and region of development are displayed in Fig. 1. The image exaggerates the actual size of the areas affected by changes for a better visualization of their location.

The results confirm previous findings: the deforestations continue in the mountains situated at the border of the North-East, Center and North-West regions of development (Kuemmerle et al., 2007; Hostert et al., 2008; Müller and Munroe, 2008; Stăncioiu et al., 2010; Dutcă and Abrudan, 2010; Knorn et al., 2012; Dumitraşcu et al., 2014; Petrişor, 2012a, 2013, 2015b; Petrişor et al., 2014; Kupková et al., 2013; Petrişor, 2015b; Vanonckelen and Van Rompaey, 2015; Andronache et al., 2016; Drăghici et al., 2016, 2017; Pintilii et al., 2016, 2017; Popovici et al., 2018; Kucsicsa and Dumitrică, 2019; Kucsicsa et al., 2019).

Urbanization is more prominent in the south (Bucharest-Ilfov and South regions of development), but also around other large urban centers (Cluj-Napoca, Braşov, and Timişoara), since previous study showed that the urbanization of developing countries occurs in the metropolitan areas (Pauchard et al., 2006; Václavík and Rogan, 2009; Grigorescu et al., 2012a, b; Petrişor, 2012b, 2017a, b; Kupková et al., 2013; Ianoş et al., 2016). However, the urbanization of the Romanian seashore (Petrişor, 2012a; Petrişor et al., 2010) seems to have stopped.

Another interesting finding is the presence of forestation centers, in the mountains situated in the western part of the country. Most likely, this result sustains the effectiveness of in-situ protection, indicating the regeneration of forests when husbandry ceased due to the protection measures (Garcia-Ruiz et al., 1996; Blakesley, 2006; Kuemmerle et al., 2006; Václavík and Rogan, 2009; Van Uytvanck, 2009; Agnoletti et al., 2011; Petrişor et al., 2014).

Last but not least, other hotspots indicate the abandonment of agriculture in the north-west of the country, most probably due to the massive emigration and loss of working population during the economic crisis (Müller and Munroe, 2008; Müller et al., 2009; Sikor et al., 2009; Prishchepov et al., 2013; Petrişor et al., 2014), and its 
development in the center (Popovici et al., 2018). An interesting phenomenon was the transformation of 'urban' land into agricultural land, attributable mostly to developing agriculture on abandoned construction sites rather than to urban agriculture, which in Romania is in its beginning stages (Enache and Popa, 2015; Panagopoulos et al., 2018); a proof is a similar transformation of urban land into forest, most likely due to the colonization of abandoned constructions sites by forest vegetation.

Apart from the hotspots, the very presence of some transitional dynamics is interesting. Floods reoccur and affect important areas, similar to the period 2000-2006 (Petrişor et al., 2010; Petrişor, 2012a). In addition to them, droughts are present; their simple presence might be an indication of the effects of climate changes (Petrişor, 2012c). It is also noteworthy mentioning that droughts tend to affect few, but large areas (Table 1).

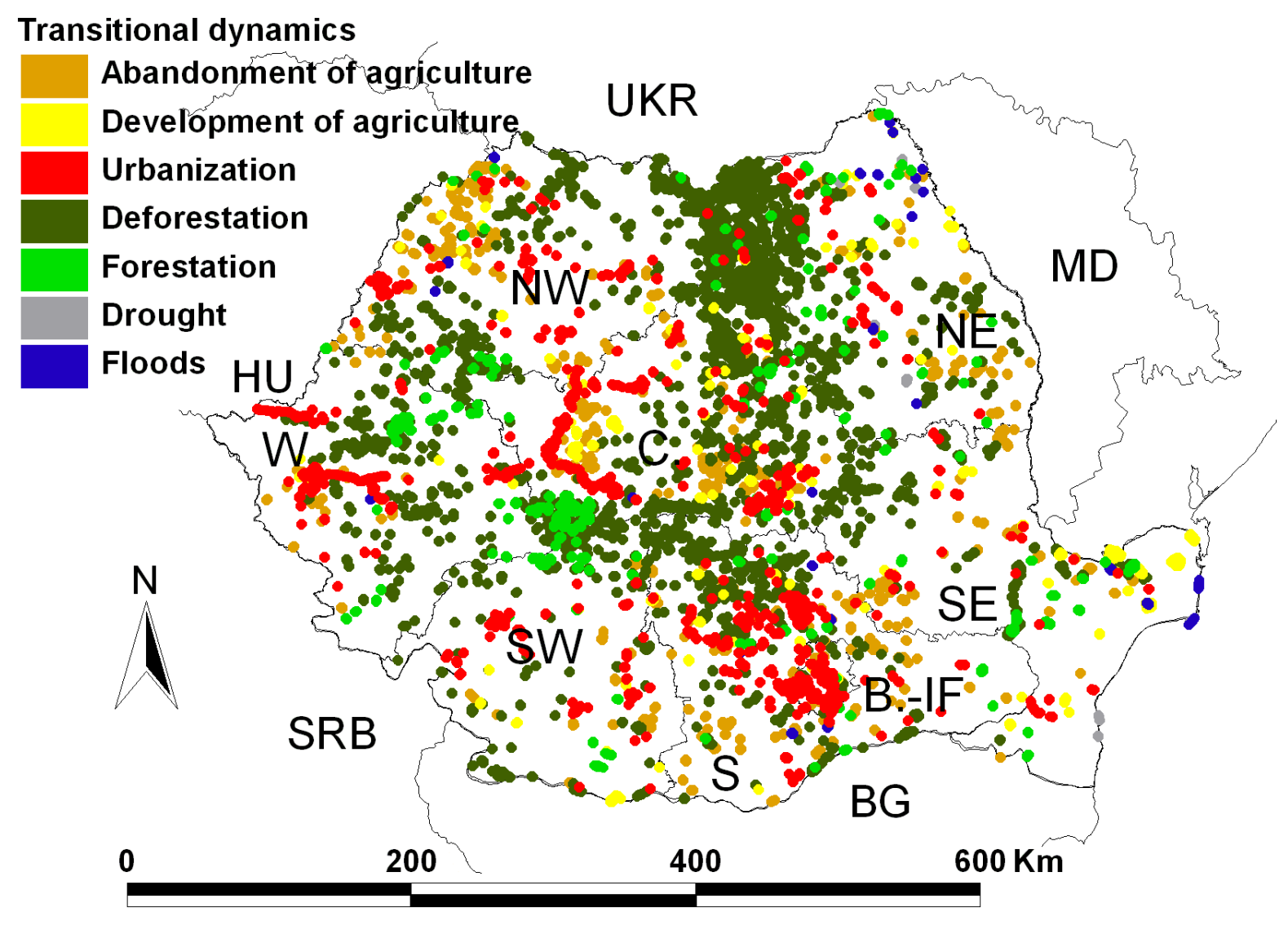

Figure 1. LCUCs in Romania by transitional dynamics and region of development (2012-2018). The contours of areas affected by changes were exaggerated for a better visualization of their location.

The numeric analysis of LCUCs occurred in Romania during 2012-2018 by transitional dynamics and region of development is presented in Tables 1 and 2 . The first table presents the overall influence of the main drivers in Romania. In order to provide an overall estimate of the fragmentation of land determined by each transitional dynamic, the table presents also the number of parcels affected. The second table includes areas affected by each transitional dynamics and region of development expressed as row values, and share of the total area of each region.

The findings in Table 1 suggest some important trends. Overall, deforestations and the abandonment of agriculture were the more prominent transitional dynamics in terms of the total area affected. As mentioned before, droughts affected large areas, even if fewer in number. Similarly, the development of agriculture has the largest average parcel 
size, suggesting that the development occurred in an organized way, probably through the association of farmers (Simulescu and Zamfir, 2015).

On the opposite size, urbanization affected many small parcels; the results must be interpreted in relationship to the relatively small size of Romanian cities, expressed as share of the total area (Petrişor, 2012b). Another transitional dynamic with a similar pattern is deforestation. Most likely, the results indicate illegal deforestations, occurring on many small parcels.

Table 1. LCUCs occurred in Romania during 2012-2018 by transitional dynamics. The table shows, in addition to the total area affected by each transitional dynamic, the number of parcels affected, as an indicator of the fragmentation of land determined by LCUCs.

\begin{tabular}{|c|c|c|c|c|}
\hline Transitional dynamic & Area & National share & No. parcels & Average size/parcel \\
\hline Abandonment of agriculture & 248 & 0.10 & 508 & 0.49 \\
\hline Deforestation & 678 & 0.28 & 2408 & 0.28 \\
\hline Development of agriculture & 160 & 0.07 & 164 & 0.98 \\
\hline Drought & 5 & 0.00 & 8 & 0.61 \\
\hline Floods & 14 & 0.01 & 31 & 0.44 \\
\hline Forestation & 102 & 0.04 & 238 & 0.43 \\
\hline Urbanization & 193 & 0.08 & 976 & 0.20 \\
\hline
\end{tabular}

Last but not least, the relatively small size of parcels affected by forestation suggests that the phenomenon occurred naturally, either by the regeneration of forests after the ceasing of husbandry in the natural protected areas, or colonization of abandoned cropland by forest vegetation (Garcia-Ruiz et al., 1996; Blakesley, 2006; Kuemmerle et al., 2006; Václavík and Rogan, 2009; Van Uytvanck, 2009; Agnoletti et al., 2011; Petrişor et al., 2014).

Table 2. LCUCs occurred in Romania during 2012-2018 by transitional dynamics and region of development. Gray shading indicate that the respective transitional dynamic was not identified or affected less than 0.01 of the area of the region.

\begin{tabular}{|c|c|c|c|c|c|c|c|c|c|c|c|c|c|c|}
\hline \multirow{3}{*}{$\begin{array}{c}\text { Region of } \\
\text { development }\end{array}$} & \multicolumn{14}{|c|}{ Transitional dynamic } \\
\hline & \multicolumn{2}{|c|}{$\begin{array}{l}\text { Abandonment } \\
\text { of agriculture }\end{array}$} & \multicolumn{2}{|c|}{ Deforestation } & \multicolumn{2}{|c|}{$\begin{array}{l}\text { Development } \\
\text { of agriculture }\end{array}$} & \multicolumn{2}{|c|}{ Drought } & \multicolumn{2}{|c|}{ Floods } & \multicolumn{2}{|c|}{ Forestation } & \multicolumn{2}{|c|}{ Urbani-zation } \\
\hline & Area & $\%$ & Area & $\%$ & Area & $\%$ & Area & $\%$ & Area & $\%$ & Area & $\%$ & Area & $\%$ \\
\hline Bucharest-Ilfov & 17 & 0.91 & 4 & 0.25 & 1 & 0.07 & 0 & 0.00 & 0 & 0.00 & 1 & 0.05 & 24 & 1.33 \\
\hline Center & 56 & 0.16 & 177 & 0.52 & 21 & 0.06 & 0 & 0.00 & 0 & 0.00 & 26 & 0.08 & 45 & 0.13 \\
\hline North-East & 23 & 0.06 & 195 & 0.53 & 7 & 0.02 & 2 & 0.01 & 2 & 0.01 & 14 & 0.04 & 10 & 0.03 \\
\hline North-West & 46 & 0.13 & 88 & 0.26 & 5 & 0.01 & 0 & 0.00 & 2 & 0.01 & 5 & 0.01 & 24 & 0.07 \\
\hline South & 49 & 0.14 & 84 & 0.24 & 6 & 0.02 & 0 & 0.00 & 2 & 0.01 & 8 & 0.02 & 35 & 0.10 \\
\hline South-East & 34 & 0.09 & 39 & 0.11 & 106 & 0.30 & 1 & 0.00 & 5 & 0.01 & 18 & 0.05 & 7 & 0.02 \\
\hline South-West & 14 & 0.05 & 39 & 0.13 & 12 & 0.04 & 0 & 0.00 & 0 & 0.00 & 15 & 0.05 & 15 & 0.05 \\
\hline West & 9 & 0.03 & 49 & 0.15 & 1 & 0.00 & 0 & 0.00 & 1 & 0.00 & 14 & 0.05 & 32 & 0.10 \\
\hline
\end{tabular}

These findings are sustained by the detailed analysis presented in Table 2 . The results confirm that floods and drought, even if present during the period, were present 
only in some regions of development. The most important changes occurred in Bucharest-Ilfov, due to urbanization (1.33\% of the area) and abandonment of agriculture $(0.91 \%)$. Apart from these, the findings are a simple confirmation of those indicated by Fig. 1.

Table 3 displays the LCUCs occurred within the Romanian natural protected areas during $2012-2018$ by their associated transitional dynamics.

The findings in Table 3 confirm the previous results, showing that LCUCs occurred within the natural protected areas, although they shouldn't (Petrişor, 2018). Most important, some of them are consequences of activities which certainly violate the protection status - deforestations, development of agriculture, and urbanization. Deforestation occurred in absolutely all types of protected areas, and the shares of areas affected by it are among the highest $(0.61 \%$ of the total area of natural parks, $0.51 \%$ in SCIs, and $0.47 \%$ in SPAs). Urbanization occurred in the protected wetlands (Ramsar), Natura 2000 sites (SCIs, SPAs, and SACs), and in the 'other' areas, affecting small shares. The development of agriculture occurred in the protected wetlands (Ramsar $-0.84 \%$ of the total area), some Natura 2000 sites (SCIs and SPAs), and in the Biosphere reserves $(1.39 \%)$ and UNESCO sites $(0.75 \%)$. Most likely, the latest are strong evidence for the illegal agricultural activities taking place within the limits of Danube Delta Biosphere Reserve (Damian, 2011), since these are the highest shares. The other drivers, indicating natural phenomena after the ceasing of the human activities, had a lesser impact.

Table 3. LCUCs occurred in Romania during 2012-2018 within the natural protected areas by transitional dynamics and region of development. Gray shading indicate that the respective transitional dynamic was not identified or affected less than 0.01 of the area.

\begin{tabular}{|c|c|c|c|c|c|c|c|c|c|c|c|c|c|c|}
\hline \multirow{3}{*}{$\begin{array}{l}\text { Type of natural } \\
\text { protected area }\end{array}$} & \multicolumn{14}{|c|}{ Transitional dynamic } \\
\hline & \multicolumn{2}{|c|}{$\begin{array}{l}\text { Abandonment } \\
\text { of agriculture }\end{array}$} & \multicolumn{2}{|c|}{ Deforestation } & \multicolumn{2}{|c|}{$\begin{array}{l}\text { Development } \\
\text { of agriculture }\end{array}$} & \multicolumn{2}{|c|}{ Drought } & \multicolumn{2}{|c|}{ Floods } & \multicolumn{2}{|c|}{ Forestation } & \multicolumn{2}{|c|}{ Urbanization } \\
\hline & Area & $\%$ & Area & $\%$ & Area & $\%$ & Area & $\%$ & Area & $\%$ & Area & $\%$ & Area & $\%$ \\
\hline $\begin{array}{l}\text { Biosphere } \\
\text { reserve }\end{array}$ & 0 & 0.00 & 6 & 0.09 & 92 & 1.39 & 2 & 0.03 & 6 & 0.08 & 5 & 0.08 & 0 & 0.00 \\
\hline UNESCO & 0 & 0.00 & 1 & 0.02 & 23 & 0.75 & 2 & 0.07 & 1 & 0.03 & 0 & 0.00 & 0 & 0.00 \\
\hline National park & 0 & 0.00 & 6 & 0.18 & 0 & 0.00 & 0 & 0.00 & 0 & 0.00 & 2 & 0.07 & 0 & 0.00 \\
\hline Natural park & 0 & 0.01 & 47 & 0.61 & 0 & 0.00 & 1 & 0.01 & 8 & 0.10 & 0 & 0.00 & 0 & 0.00 \\
\hline Ramsar & 1 & 0.01 & 26 & 0.24 & 92 & 0.84 & 2 & 0.02 & 6 & 0.06 & 12 & 0.11 & 1 & 0.01 \\
\hline$S C I$ & 25 & 0.05 & 236 & 0.51 & 95 & 0.20 & 3 & 0.01 & 7 & 0.02 & 50 & 0.11 & 6 & 0.01 \\
\hline$S P A$ & 30 & 0.08 & 183 & 0.47 & 110 & 0.28 & 4 & 0.01 & 7 & 0.02 & 43 & 0.11 & 7 & 0.02 \\
\hline$S A C$ & 0 & 0.00 & 2 & 0.12 & 0 & 0.00 & 0 & 0.00 & 0 & 0.00 & 1 & 0.07 & 0 & 0.00 \\
\hline Natural reserve & 1 & 0.21 & 0 & 0.09 & 0 & 0.00 & 0 & 0.00 & 0 & 0.02 & 0 & 0.00 & 0 & 0.00 \\
\hline Other & 0 & 0.01 & 9 & 0.33 & 0 & 0.00 & 0 & 0.01 & 1 & 0.02 & 1 & 0.04 & 0 & 0.01 \\
\hline
\end{tabular}

In summary, the results show that the most important transitional dynamics are deforestations and the abandonment of cropland. Deforestations are most likely illegal, occurring on many small parcels. Both transitional dynamics are characteristic to Eastern-European countries undergoing the post-socialist property restitution (Kuemmerle et al., 2006, 2007; Hostert et al., 2008; Müller and Munroe, 2008; Václavík and Rogan, 2009; Stăncioiu et al., 2010; Dutcă and Abrudan, 2010; Knorn et al., 2012; Dumitraşcu et al., 2014; Petrişor, 2012a, 2013, 2015b; Petrişor et al., 2014; Kupková et 
al., 2013; Petrişor, 2015b; Vanonckelen and Van Rompaey, 2015; Andronache et al., 2016; Drăghici et al., 2016, 2017; Pintilii et al., 2016, 2017; Popovici et al., 2018; Kucsicsa and Dumitrică, 2019; Kucsicsa et al., 2019). Most important, deforestations were also found within the natural protected areas, along with other transitional dynamics indicating the human pressure (urbanization and development of agriculture). Apart from rising serious questions on the effectiveness of protection, these findings indicate that developing economies, particularly in a post-socialist culture, sacrifice the long-term interests related to the protection of the environment for a short-term profit (Ianoş et al., 2009, 2012).

It must also be stressed out that this study is subject to potential limitations associated to the use of CORINE data, including misclassification errors (Jansen, 2007; Pelorosso et al., 2011; Verburg et al., 2011; Petrişor et al., 2010, 2014). However, such findings might only influence slightly the figures, but the findings remain valid, as indicated by their consistence with previous studies carried out in Romania and in other Eastern-European countries.

\section{Conclusions}

Starting from the importance of studying land cover and use changes in relationship to their associated transitional dynamics for ensuring a sustainable development, this study aimed to look at the most recent land cover and use changes in Romania and its natural protected areas, by the means of geo-spatial analysis. The results indicate that the most important transitional dynamics are deforestations and the abandonment of cropland, which are a consequence of the post-socialist property restitution and were found in other Eastern-European countries. Furthermore, the study found evidence for transitional dynamics indicating the human pressure within the natural protected areas, including urbanization, development of agriculture, and deforestation. Although the study is subject to limitations related to the use of CORINE data, the findings are important for understanding the environmental impact of socio-economic drivers, and provide additional evidence for the fact that emerging economies tend to sacrifice the environment during the economic crises.

\section{References}

1. Agnoletti M., Cargnello G., Gardin L., Santoro A., Bazzoffi P., Sansone L., Pezza L., Belfiore N. (2011), Traditional landscape and rural development: comparative study in three terraced areas in northern, central and southern Italy to evaluate the efficacy of GAEC standard 4.4 of cross compliance, Italian Journal of Agronomy 6: 121-139.

2. Andronache I. C., Ahammer H., Jelinek H. F., Peptenatu D., Ciobotaru Ana-Maria, Drăghici C. C., Pintilii R. D., Simion A. G., Teodorescu Camelia (2016), Fractal analysis for studying the evolution of forests, Chaos, Solitons \& Fractals 91: 310-318.

3. Baumann M., Kuemmerle T., Elbakidze Marine, Ozdogana M., Radeloff V. C., Keuler N. S., Prishchepov A. V., Kruhlovd I., Hostert P. (2011), Patterns and drivers of post-socialist farmland abandonment in Western Ukraine, Land Use Policy 28(3): 552-562.

4. Bălteanu D., Popovici E.-A. (2010), Land use changes and land degradation in post-socialist Romania, Romanian Journal of Geography 54(2): 95-105.

5. Bičík I., Janoušek Z., Kabrda J. (2015), Czechia: Changes in landscape use in the transformation period, Romanian Journal of Geography 59(1): 3-17.

6. Bielecka Elzbieta, Jenerowicz Agnieszka (2019), Intellectual Structure of CORINE Land Cover Research Applications in Web of Science: A Europe-Wide Review, Remote Sensing 11(17): 2017. 
7. Blakesley D. (2006), Woodland Creation for Wildlife: a guide to creating new woodland for wildlife in Kent and East Sussex, East Malling Research, Kent, UK.

8. Chambers N., Simmons C., Wackernagel M. (2000), Sharing Nature's Interest: Ecological Footprints as an Indicator of Sustainability, Earthscan, London, UK.

9. Cocheci R. M., Ianoş I., Sârbu C. N., Sorensen A., Saghin Irina, Secăreanu G. (2019), Assessing environmental fragility in a mining area for specific spatial planning purposes, Moravian Geographical Reports 27(3): 169-182.

10. Cojocariu Luminiţa., Horablaga M. N., Marian F., Bostan C., Mazăre V., Stroia M. S. (2010), Implementation of the ecological European network "Natura 2000" in the area of grasslands and hayfields, Research Journal of Agricultural Science 42(1): 398-404.

11. Damian Nicoleta (2011), Unemployment and poverty in the Danube Delta settlements. Territorial disparities, Romanian Journal of Geography 55(1): 11-22.

12. Dale Virginia H., Efroymnson Rebecca A., Kline K. L. (2011), The land use - climate change energy nexus, Landscape Ecology 26: 755-773.

13. Dragotă Carmen Sofia, Dumitraşcu Monica, Grigorescu Ines, Kucsicsa G. (2011), The Climatic Water Deficit in South Oltenia Using the Thornthwaite Method, Forum geografic. Studii şi cercetări de geografie şi protecţia mediului 10(1): 140-148.

14. Drăghici C. C., Andronache I., Ahammer H., Peptenatu D., Pintilii R. D., Ciobotaru Ana-Maria, Simion A. G., Dobrea R. C., Diaconu D. C., Vișan M. C., Papuc R. M. (2017), Spatial evolution of forest areas in the northern Carpathian Mountains of Romania, Acta Montanistica Slovaca 22(2): 95-106.

15. Drăghici C. C., Peptenatu D., Simion A. G., Pintilii R. D., Diaconu D. C., Teodorescu Camelia, Papuc R. M., Grigore A. M., Dobrea C. R. (2016), Assessing economic pressure on the forest fund of Maramureş County - Romania, Journal of Forest Science 62(4): 175-185.

16. Dumitraşcu Monica, Grigorescu Ines, Cuculici Roxana, Dumitraşcu C., Năstase Mihaela, Geacu S. (2014), Assessing long-term changes in forest cover in the South West Development Region, Romania, Forum geografic. Studii şi cercetări de geografie şi protecţia mediului 13(1): 76-85.

17. Dutcă I., Abrudan I. V. (2010), Estimation of forest land-cover change in Romania, between 1990 and 2006, Bulletin of the Transylvania University of Braşov Series II: Forestry, Wood Industry, and Agricultural Food Engineering 52: 33-36.

18. Elias P., Dekolo S., Babatola O. (2012), Land use change modelling in developing countries: Issues and prospects, International Journal of Geography and Geology 1(1): 23-41.

19. Enache Cristina, Popa Andreea (2015), Urban Agriculture. Perception-Awareness-Necessity, in: Sandu A., Frunză A., Ciulei T., Gorghiu G., Petrovici A. (Eds.), LUMEN: Rethinking Social Action. Core Values, Medimond Monduzzi International Proceedings Division, Italy, pp. 531-535.

20. Faeth P., Hanson L. (2016), A research agenda for the energy, water, land, and climate nexus, Journal of Environmental Studies and Sciences 6(1): 123-126.

21. Foley J. A., Defries Ruth, Asne G. P., Barford Carol, Bonan G., Carpenter S. R., Chapin F. S., Coe M. T., Daily Gretchen C., Gibbs Holly K., Helkowski J. H., Holloway Tracey, Howard Erica A., Kucharik C. J., Monfreda C., Patz J. A., Prentice C, Ramankutty N., Snyder P. K. (2005), Global Consequences of Land Use, Science 309(5734): 570-574.

22. Garcia-Ruiz J. M., Lasanta T., Ruiz-Flano Purificación, Ortigosa L., White Sue, Gonzhlez Constanza, Martí C. (1996), Land-use changes and sustainable development in mountain areas: a case study in the Spanish Pyrenees, Landscape Ecology 11(5): 267-277.

23. Grădinaru Simona Rodica, Iojă C. I., Pătru-Stupariu Ileana, Hersperger Anne M. (2017), Are Spatial Planning Objectives Reflected in the Evolution of Urban Landscape Patterns? A Framework for the Evaluation of Spatial Planning Outcomes, Sustainability 9(8): 1279.

24. Grigorescu Ines, Mitrică Bianca, Kucsicsa G., Popovici Elena-Ana, Dumitraşcu Monica, Cuculici Roxana (2012), Post-communist land use changes related to urban sprawl in the Romanian metropolitan areas, Human Geographies - Journal of Studies and Research in Human Geography 6(1): 35-46.

25. Grigorescu Ines, Mitrică Bianca, Mocanu Irena, Ticană Nicoleta (2012), Urban sprawl and residential development in the Romanian metropolitan areas, Romanian Journal of Geography 56(1): 43-59. 
26. Hagenauer J., Helbich M. (2012), Mining urban land-use patterns from volunteered geographic information by means of genetic algorithms and artificial neural networks, International Journal of Geographical Information Science 26(6): 963-982.

27. Hostert P., Kuemmerle P., Prishchepov A., Sieber Anika, Lambin E. F., Radeloff V. C. (2011), Rapid land use change after socio-economic disturbances: the collapse of the Soviet Union versus Chernobyl, Environmental Research Letters 6(4): 045201.

28. Hostert P., Kuemmerle T., Radeloff V. C., Müller D. (2008), Post Socialist Land-Use and Land-Cover Change in the Carpathian Mountains, International Human Dimensions Programme Update 11(2): 70-73.

29. Ianoş I., Jones R. (2019), Local aspects of change in the rural-urban fringe of a metropolitan area: A study of Bucharest, Romania, Habitat International 91:102026.

30. Ianoş I., Peptenatu D., Zamfir Daniela (2009), Respect for environment and sustainable development, Carpathian Journal of Earth and Environmental Sciences 4(1): 81-93.

31. Ianoş I., Petrişor A.-I., Stoica Ilinca Valentina, Sârbu C. N., Zamfir Daniela, Cercleux Andreea Loretta (2011), The different consuming of primary eco-energies and their degradation in territorial systems, Carpathian Journal of Earth and Environmental Sciences 6(2):251-260.

32. Ianoş I., Sîrodoev I., Pascariu G., Henebry G. (2016), Divergent patterns of built-up urban space growth following post-socialist changes, Urban Studies 53(15): 3172-3188.

33. Ianoş I., Sîrodoev I., Pascariu, G. (2012), Land-use conflicts and environmental policies in two post-socialist urban agglomerations: Bucharest and Chişinău, Carpathian Journal of Earth and Environmental Sciences 7(4): 125-136.

34. Ianoş I., Sorensen A., Merciu Cristina (2017), Incoherence of urban planning policy in Bucharest: Its potential for land use conflict, Land Use Policy 60: 101-112.

35. Jansen Louisa J. M. (2007), Harmonization of land use class sets to facilitate compatibility and comparability of data across space and time, Journal of Land Use Science 1(2-4):127-156.

36. Kati V., Hovardas T., Dieterich M., Ibisch P. L., Mihok Barbara, Selva Nuria (2015), The Challenge of Implementing the European Network of Protected Areas Natura 2000, Conservation Biology 29(1): 260-270.

37. Knorn J., Kuemmerle T., Radeloff V. C., Szabo Alina, Mîndrescu M., Keeton W. S., Abrudan I., Griffiths P., Gancz V., Hostert P. (2012), Forest restitution and the protected area effectiveness in post-socialist Romania, Biological Conservation 146(1): 204-212.

38. Kucsicsa G., Dumitrică C. (2019), Spatial modelling of deforestation in Romanian Carpathian Mountains using GIS and Logistic Regression, Journal of Mountain Science 16(5): 1005-1022.

39. Kucsicsa G., Popovici Elena Ana, Bălteanu D., Grigorescu Ines, Dumitraşcu Monica, Mitrică Bianca (2019), Future land use/cover changes in Romania: regional simulations based on CLUE-S model and CORINE land cover database, Landscape and Ecological Engineering 15(1): 75-90.

40. Kuemmerle T., Hostert P., Radeloff V. C, Perzanowski K., Kruhlov I. (2007), Post-socialist forest disturbance in the Carpathian border region of Poland, Slovakia, and Ukraine, Ecological Applications 17(5): 1279-1295.

41. Kuemmerle T., Hostert P., Radeloff V. C., van derLinden S., Perzanowski K., Kruhlov I. (2008), Cross-border Comparison of Postsocialist Farmland Abandonment in the Carpathians, Ecosystems 11(4): 614-628.

42. Kuemmerle T., Müller D., Griffiths P., Rusu Marioara (2009), Land use change in Southern Romania after the collapse of socialism, Regional Environmental Change 9: 1.

43. Kuemmerle T., Radeloff V. C, Perzanowski K., Hostert P. (2006), Cross-border comparison of land cover and landscape pattern in Eastern Europe using a hybrid classification technique, Remote Sensing of Environment 103(4): 449-464.

44. Kupková Lucia, Bičík I., Najman J. (2013), Land Cover Changes along the Iron Curtain 1990-2006, Geografie 118(2): 95-115.

45. Lambin E. F., Meyfroidt P. (2010), Land use transitions: Socio-ecological feedback versus socio-economic change, Land Use Policy 27(2): 108-118.

46. Lambin E. F., Rounsevell M. D. A., Geist H. J. (2000), Are agricultural land-use models able to predict changes in land-use intensity?, Agriculture, Ecosystems and Environment 82(1-3): 321-331. 
47. Müller D., Kuemmerle T., Rusu M., Griffiths P. (2009), Lost in transition: determinants of post-socialist cropland abandonment in Romania, Journal of Land Use Science 4(1-2): 109-129.

48. Müller D., Munroe Darla K. (2008), Changing Rural Landscapes in Albania: Cropland Abandonment and Forest Clearing in the Postsocialist Transition, Annals of the Association of American Geographers 98(4): 1-22.

49. Panagopoulos T., Jankovska Ilze, Boştenaru Dan Maria (2018), Urban green infrastructure: The role of urban agriculture in city resilience, Urbanism Architecture Constructions 9(1): 55-70.

50. Pauchard A., Aguayo M., Peña, Urrutia R. (2006), Multiple effects of urbanization on the biodiversity of developing countries: The case of a fast-growing metropolitan area (Concepción, Chile), Biological Conservation 127(3): 272-281.

51. Pelorosso R., Della Chiesa S., Tappeiner U., Leone A., Rocchini D. (2011), Stability analysis for defining management strategies in abandoned mountain landscapes of the Mediterranean basin, Landscape and Urban Planning 103(3-4):335-346.

52. Petrişor A.-I. (2010), GIS analysis of wetland cover by NATURA 2000 sites, Environmental Engineering and Management Journal 9(2): 269-273.

53. Petrişor A.-I. (2012a), Dynamics of the environmental transformation processes during 1990-2006 in Romania reflected by land cover and use changes, Present Environment and Sustainable Development 6(1):353-365.

54. Petrişor A.-I. (2012b), Land cover and land use analysis of urban growth in Romania, Human Geographies 6(1):47-51.

55. Petrişor A.-I. (2012c), Land cover and use changes and predicted climate changes in Romania: Connections underlined by their spatial distributions, Oltenia. Studii şi comunicări. Ştiinţele Naturii 28(1): 141-148.

56. Petrişor A.-I. (2015a), Land cover and land use changes reflecting the environmental impacts of declining economies. Case study: south-west development region, Romania, Romanian Journal of Geography 59(1):29-39.

57. Petrişor A.-I. (2015b), Using CORINE data to look at deforestation in Romania: Distribution \& possible consequences, Urbanism Architecture Constructions 6(1):83-90.

58. Petrişor A.-I. (2016a), Assessing the efficiency of the Romanian natural protected areas in conserving prioritary habitats, Oltenia. Studii şi comunicări. Ştiinţele Naturii 32(1): 191-194.

59. Petrişor A.-I. (2016b), Brief critical analysis of concepts used for assessing the market value to ecosystem goods and services in urban and spatial plans, Journal of Urban and Landscape Planning 1: 98-108.

60. Petrişor A.-I. (2017), Spatial ecological, biogeographical and landform distribution of 2006-2012 land cover and use changes in Romania, Oltenia. Studii şi comunicări. Ştiinţele Naturii 33(1): 147-153.

61. Petrişor A.-I. (2018), 2006-2012 land cover and use changes in Romanian natural protected areas, Oltenia. Studii şi comunicări. Ştiinţele Naturii 34(1): 247-252.

62. Petrişor A.-I., Grigorovschi M., Meiţă V., Simion-Melinte C.-P. (2014), Long-term environmental changes analysis using CORINE data, Environmental Engineering and Management Journal 13(4):847-860.

63. Petrişor A.-I., Ianoş I., Tălângă C. (2010), Land cover and use changes focused on the urbanization processes in Romania, Environmental Engineering and Management Journal 9(6): 765-771.

64. Petrişor A.-I., Petrişor Liliana Elza (2015), Assessing microscale environmental changes: CORINE vs. the Urban Atlas, Present Environment and Sustainable Development 9(2): 95-104.

65. Petrişor A.-I., Petrişor Liliana Elza (2017a), 2010-2012 land cover and use changes in Romania - an overall assessment based on CORINE data, Present Environment and Sustainable Development 11(2): 119-127.

66. Petrişor A.-I., Petrişor Liliana Elza (2017b), Using spatial metrics to assess the efficacy of biodiversity conservation within the Romanian Carpathian Convention area, Present Environment and Sustainable Development 11(1): 35-43. 
67. Petrişor A.-I., Petrişor Liliana Elza (2018), Transitional dynamics based trend analysis of land cover and use changes in Romania during 1990-2012, Present Environment and Sustainable Development 12(2): 215-231.

68. Petrişor A.-I., Sîrodoev I., Ianoş I. (2020), Trends in the national and regional transitional dynamics of land cover and use changes in Romania, Remote Sensing 12(2): 230.

69. Pintilii R. D., Andronache I., Diaconu D. C., Dobrea R. C., Zeleňáková Martina, Fensholt R., Peptenatu D., Drăghici C. C., Ciobotaru Ana-Maria (2017), Using Fractal Analysis in Modeling the Dynamics of Forest Areas and Economic Impact Assessment: Maramureş County, Romania, as a Case Study, Forests 8(1): 25.

70. Pintilii R. D., Andronache I. C., Simion A. G., Drăghici C. C., Peptenatu D., Ciobotaru Ana Maria, Dobrea R. C., Papuc R. M. (2016), Determining forest fund evolution by fractal analysis (Suceava-Romania), Urbanism Architecture Constructions 7(1): 31-42.

71. Popa Andreea, Enache Cristina (2019), Decoding the Urban Landscape, Postmodern Openings 10(1):272-279.

72. Popovici Elena-Ana, Bălteanu D., Kucsicsa G. (2013), Assessment of changes in land-use and land-cover pattern in Romania using CORINE land cover database, Carpathian Journal of Earth and Environmental Sciences 8(4): 195-208.

73. Popovici Elena-Ana, Kucsicsa G., Bălteanu D, Grigorescu Ines, Mitrică Bianca, Dumitraşcu Monica, Damian Nicoleta (2018), Past and future land use/cover flows related to agricultural lands in Romania. An assessment using CLUE-S model and CORINE land cover database, Carpathian Journal of Earth and Environmental Sciences 13(2): 613-628.

74. Prishchepov A. V., Müller D., Dubinin M., Baumann M., Radeloff V. C. (2013), Determinants of agricultural land abandonment in post-Soviet European Russia, Land Use Policy 30(1): 873-884.

75. Sikor T., Müller D., Stahl J. (2009), Land Fragmentation and Cropland Abandonment in Albania: Implications for the Roles of State and Community in Post-Socialist Land Consolidation, World Development 37(8): 1411-1423.

76. Simulescu D., Zamfir Andreea (2015), Dynamics of land use changes in Dăbuleni plain (southwestern Romania), Annals of Valahia University of Târgovişte. Geographical Series 15(2): 77-84.

77. Stan Mari-Isabela, Vintilă D.-F. (2016), Mitigation of coastal erosion by beach nourishment of Romanian Black Sea Shore, Analele Universităţii Ovidius Constanţa Seria Construcţii 18: 25-32.

78. Stăncioiu P. T., Abrudan I. V., Dutcă I. (2010), The Natura 2000 ecological network and forests in Romania: implications on management and administration, International Forestry Review 12(1): 106-113.

79. Van Uytvanck J. (2009), The role of large herbivores in woodland regeneration patterns, mechanisms and processes, Research Institute for Nature and Forest, Brussels, Belgium.

80. Vanonckelen S., Van Rompaey A. (2015), Spatiotemporal Analysis of the Controlling Factors of Forest Cover Change in the Romanian Carpathian Mountains, Mountain Research and Development 35(4): 338-350.

81. Václavík T., Rogan J. (2009), Identifying Trends in Land Use/Land Cover Changes in the Context of Post-Socialist Transformation in Central Europe: A Case Study of the Greater Olomouc Region, Czech Republic, GIScience \& Remote Sensing 46(1): 54-76.

82. Verburg P. H., de Koning G. H. J., Kok K., Veldkamp A., Bouma J. (1999), A spatial explicit allocation procedure for modelling the pattern of land use change based upon actual land use, Ecological Modelling 116(1): 45-61.

83. Verburg P. H., Neumann Kathleen, Noll Linda (2011), Challenges in using land use and land cover data for global change studies, Global Change Biology 17(2):974-989. 